\title{
COVID-19 Patogenezinde Diyetin Bağırsak-Akciğer Ekseni Üzerine Potansiyel Etkileri
}

\section{Potential Effects of Diet on the Gut-Lung Axis in the Pathogenesis of COVID-19}

\author{
Aslı YiĞiT 1*(D), Aliye KUYUMCU 1(D)
}

${ }^{1}$ Süleyman Demirel Üniversitesi, Sağlık Bilimleri Fakültesi, Beslenme ve Diyetetik Bölümü, Isparta, Türkiye

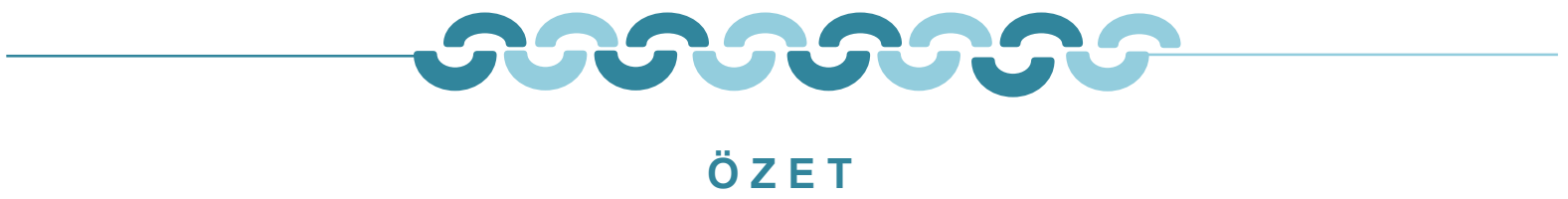

Dünya çapında milyonlarca insan SARS-CoV-2 virüsünün neden olduğu ve COVID-19 olarak bilinen yeni koranavirüs hastalığından etkilenmiş durumdadır. COVID-19 enfeksiyonu, asemptomatik bir enfeksiyon olarak ortaya çıkabildiği gibi öksürük, titreme, ateş, yorgunluk ve nefes darlığı şeklinde belirtilerle karakterize bir solunum yolu hastalığı olarak da görülebilmektedir. Çoklu organ yetmezliği olan ağır hastalarda, şiddetli akut inflamasyon ve sitokin fırtınası olarak adlandırılan aşırı sitokin salınımı söz konusudur. Virüs ile enfekte bazı kişilerde diyare ve gastrointestinal sistemde tutulum görülmesi bağırsak mikrobiyotasını ve bağırsak-akciğer eksenini akla getirmektedir. COVID-19'un kötü klinik sonuçları yaşlılık ve komorbidite varlığı gibi spesifik risk faktörleri ile ilişkili olması ve aynı zamanda bu risk faktörlerinin de sağlıksız mikrobiyota ile ilişkili olması bu intimali kuvvetlendirmektedir. Bağırsak-akciğer ekseninin COVID-19 için çift yönlü hareket ettiği düşünülmektedir. Mikrobiyota kaynaklı endotoksinler ve metabolitler, akciğerleri dolaşım aracılığı ile etkileyebilmekte ve akciğerde inflamasyon oluştuğunda bu durum ise bağırsak mikrobiyotasını etkileyebilmektedir. Bununla birlikte bağırsak mikrobiyotası ile immün sistem arasındaki denge halinde bozulma meydana geldiğinde inflamatuar süreçler başlamaktadır. Diyet, bağırsak mikrobiyotasının şekillenmesinde önemli bir rol oynamaktadır ve bağırsak-akciğer ekseni boyunca etki eden farklı diyet faktörleri gündeme gelmiştir. Bunlardan kısa zincirli yağ asitlerinin, bağırsak-akciğer ekseni boyunca anti-inflamatuar ve immün yanıtı düzenleyici etkisi olduğu düşünülmektedir. Polifenoller, vitamin ve mineraller gibi besin bileşenlerinin bağırsak mikrobiyotası üzerinde immün yanıtı düzenleyici önemli etkileri bulunabilmektedir. Probiyotikler, prebiyotikler ve diyet lifi gibi diyet takviyeleri ile birlikte kişiselleştirilmiş, bütüncül bir diyet, COVID-19'dan etkilenen hastalarda iyileşmeyi hızlandırmak ve klinik sonuçları geliştirmek için umut vadeden bir yaklaşım olabilir. Bu derlemenin amacı, bağırsak-akciğer ekseni ve mikrobiyota ilişkili diyet faktörleri ve COVID-19 üzerine potansiyel etkilerinin açıklanmasıdır.

Anahtar Kelimeler: COVID-19, mikrobiyota, diyet, bağırsak-akciğer ekseni

Alınış / Received: 17.02.2021 Kabul / Accepted: 12.11.2021 Online Yayınlanma / Published Online: 20.12.2021 


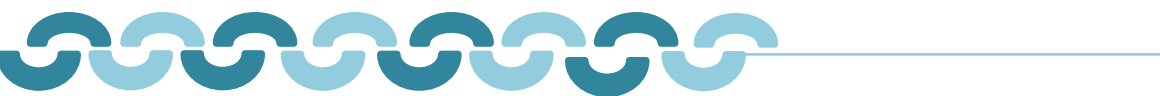

\begin{abstract}
A B S T R A C T
Millions of people around the world are affected by the novel coranavirus disease known as COVID-19, caused by the SARS-CoV-2 virus. COVID-19 infection can be observed as an asymptomatic infection, or a respiratory disease characterized by symptoms such as cough, fever, fatigue and shortness of breath. Severe acute inflammation and cytokine release can be detected in patients with multiple organ failure. Diarrhea and gastrointestinal involvement in some people infected with the virus suggest the role of gut microbiota and the gutlung axis. The bad clinical consequences of COVID-19 are associated with specific risk factors such as old age and the presence of comorbidity, and at the same time, these risk factors are also associated with unhealthy microbiota. The gut-lung axis is thought to be bidirectional for COVID-19. Microbiota-derived endotoxins and metabolites can affect the lungs through circulation, and when inflammation occurs in the lungs, this can affect the intestinal microbiota. When the balance between the intestinal microbiota and the immune system is disrupted, inflammatory processes begin. Diet plays an important role in shaping the gut microbiota, and different dietary factors that act along the gut-lung axis have come into question. Short-chain fatty acids are thought to have anti-inflammatory and immune regulatory effects along the gut-lung axis. Components such as polyphenols can have important effects on the intestinal microbiota thus, regulating the immune response. A personalized diet combined with dietary supplements such as probiotics, prebiotics and dietary fiber could be a promising approach to accelerate recovery and improve clinical outcomes in patients affected by COVID-19. The aim of this review is to describe the gut-lung axis and microbiota-related dietary factors and their potential effects on COVID-19.
\end{abstract}

\section{Giriş}

Dünya, 2019 yılının sonunda baş gösteren ve Şiddetli Akut Solunum Sendromu Koronavirüsü 2'nin (SARS-CoV-2) neden olduğu COVID-19 olarak adlandırılan yeni koronavirüs hastalığı nedeni ile büyük bir halk sağlığı kriziyle yüzleşmektedir. Bilinen ilk COVID-19 vakasının, Çin'in Hubei Eyaletindeki Wuhan şehrinde görüldüğü bildirilmiştir ve buradan başlayarak Dünya çapında her kıtaya hızla yayılmıştır [1]. Dünya Sağlık Örgütü tarafından 11 Mart 2020'de bir koronavirüs pandemisi olarak kabul edilmiştir ve günümüze kadar milyonlarca insanı etkisi altında bırakmıştır [2].

Virüs, doğada yaygın bulunan ve $\beta$-koronavirüsler olarak bilinen geniş bir virüs sınıfından gelmektedir [1]. Kuşlarda ve memelilerde enzootik enfeksiyonlar daha yaygın olmasına rağmen, koronavirüsler insanları da enfekte etmektedir. Koronavirüs enfeksiyonu, 2002'de SARS-CoV kaynaklı Şiddetli Akut Solunum Sendromu (SARS) ve ardından 2012'de ve MERS-CoV kaynaklı Orta Doğu Solunum Sendromu (MERS) salgını ile karşımıza çıkmıştır [2].

SARS-CoV-2, tipik olarak solunum sistemini etkileyen zarflı bir RNA virüsüdür. Virüsün bilinen ana bulaşma yolu, enfekte bir kişi hapşırdığında veya öksürdüğünde oluşan damlacıkların veya diğer mukustan oluşan damlacıkların yayılması şeklindedir [3]. SARS-CoV-2, anjiyotensin dönüştürücü enzim-2 (ACE2) reseptörü aracılığıyla hücreye giriş yapmaktadır ve bu sayede alveolar epitel hücrelere bağlanarak ağırlıklı olarak alt solunum yolunu enfekte etmektedir [4]. Bağlandıktan sonra, inflamasyonla ilişkili belirtiler ortaya çıkmakta ve antijen sunan hücrelerin toplanması yoluyla immün sistem yanıt göstermektedir [5]. COVID-19 enfeksiyonu, asemptomatik bir enfeksiyon olarak ortaya çıkabilmekte veya öksürük, titreme, ateş, yorgunluk ve nefes darlığı gibi belirtilerle hafif bir üst solunum yolu hastalığı olarak da görülebilmektedir [6]. Ağır vakalarda gözlemlenen en yaygın komplikasyonlar; sepsis, akut solunum sıkıntısı sendromu (acute respiratory distress syndromeARDS), kalp yetmezliği ve septik şok şeklindedir. Bununla birlikte, solunum yetmezliği ile şiddetli viral pnömoni, ölüme yol açabilmektedir [7]. Çoklu organ yetmezliği olan hastalarda, şiddetli akut 
inflamasyon ve sitokin salınımı söz konusudur [8]. COVID-19 ile ilişkili inflamasyonun ve ciddi vakalarda sitokin fırtınasının hastalığın klinik sonuçlarında önemli bir rol oynadığı görülmektedir. Dahası, COVID-19 hastalarında bulaşıcı olmayan kronik hastalıkların da varlığı, inflamatuar patolojiyi şiddetlendirebilmekte ve olumsuz sonuçlar ile mortalite riskini arttırabilmektedir [1].

SARS koronavirüs viral RNA'sının, hastalık başlangıcından sonra bazı hastaların solunum sekresyonlarında ve fekal örneklerinde tespit edilebildiğini, ancak üçüncü haftadan sonra canlı virüsün elde edilemediği öne sürülmüştür [9]. Bununla ilgili güncel bir veri, SARS-CoV-2 RNA'sının bazı COVID-19 hastalarının fekal örneklerinde tespit edilebileceğini göstermektedir [10]. Enfekte olan bazı hastaların diyare gibi gastrointestinal bulguları göstermesi, bağırsak-akciğer ekseninde ve belki de bağırsak mikrobiyotasında bir tutulum olasılığına işaret etmektedir. Bu bakımdan, COVID-19'un bağırsak mikrobiyotasına etkisi ve bağırsak mikrobiyotasının da akciğer sağlığı üzerine etkisi ile ilgili çalışmalara ağırlık verilmiş durumdadır [11].

Şu anda, COVID-19 hastalarını hızla teşhis etmek ve izole etmek için dünya çapında büyük bir çaba varken aynı zamanda, hastalığın şiddetli etkilerine karşı koyabilecek tedavi yöntemleri ve müdahaleleri araştırımaktadır. Bazı tedavi ajanları umut verici görünmekle birlikte, şu anda COVID-19 için önerilen herhangi bir tedavi için insan çalışmalarında güvenlilik ve etkinlik kanıtı yoktur [1]. Bu tedavilere ek olarak, spesifik diyet takviyeleri ve COVID-19 hastalık sürecine potansiyel etkileri oldukça ilgi kazanmış bir konudur. Bu nedenle bu derlemenin amacı COVID-19 ve bağırsak-akciğer ekseni ilişkisi ile bu eksen boyunca potansiyel olarak bağırsak mikrobiyotasını modüle eden diyet faktörlerini açıklamaktır.

\section{Bağırsak Mikrobiyotası ve Bağırsak-Akciğer Ekseni}

İnsan bağırsak mikrobiyotası, anaerobik bakterilerin baskın olduğu 200'den fazla tür dahil olmak üzere yaklaşık $10^{14}$ bakteri hücresinden oluşmaktadır. Bağırsak mikrobiyotası doğum şekli, beslenme tipi ve katı yiyeceklerin alımı beraberinde belirli bakteri türleri tarafından kolonileşmektedir [12]. Bağırsak mikrobiyotası yaşam boyunca diyet, gastrointestinal enfeksiyonlar, kullanılan ilaçlar (başlıca antibiyotikler), yaş, vücut ağırlığı, geçirilmiş cerrahi operasyonlar ve eşlik eden hastalıklardan etkilenmektedir. Bağırsak mikrobiyotası tarafından gerçekleştirilen ve sağlık üzerinde etkisi olan 3 önemli süreç bulunmaktadır ve bunlar; konakçı metabolizması, besin emilimi ve immün işlev şeklindedir. Bağırsak mikrobiyotası, mukozal yüzeylerin bütünlüğünü ve bağırsak geçirgenliğini etkileyen biyoaktif metabolitler de salgılamaktadır. Bu nedenle, insan bağırsak mikrobiyotası, genel sağlık ve devamlıığı için önemli bir rol oynamaktadır [13]. Bağırsak mikrobiyotasında görülen olumsuz değişiklikler "bağırsak disbiyozu" olarak adlandırılmaktadır ve Tip 2 diyabet, obezite ve depresyon gibi çeşitli hastalıklarla ilişkilendirilmektedir [14].

Bağırsak mikrobiyotasına benzer şekilde akciğerlerde de farklı mikroorganizmaların varlığı bilinmektedir [15]. Yaşam tarzı, diyet, sigara kullanımı, antibiyotikler ve kortikosteroidler gibi belirli ilaçların kullanımı dahil olmak üzere çok sayıda değişken akciğer mikrobiyotasını etkileyebilmektedir [16]. Bağırsak mikrobiyotasında Bacteroidetes ve Firmicutes'in baskın olduğu görülürken, akciğerlerde Bacteroidetes, Firmicutes ve Proteobacteria baskın bulunmuştur. İlginç bir şekilde, bağırsak mikrobiyotası ve akciğerler arasında "bağırsak-akciğer ekseni" olarak adlandırılan bir etkileşimin olduğu ve bağırsak mikrobiyotasının akciğer sağlığını etkilediği öne sürülmektedir. Bağırsak-akciğer ekseninin çift yönlü olduğu düşünülmektedir, yani mikrobiyota kaynaklı endotoksinler ve mikrobiyal metabolitler akciğerleri dolaşım aracılığı ile etkileyebilmekte ve akciğerde inflamasyon oluştuğunda bu durum bağırsak mikrobiyotasını etkileyebilmektedir $[17,18]$.

Akciğer mikrobiyomunun da bağırsak mikrobiyomu kadar immün sistemi harekete geçirmek için önemli olduğu kabul edilmektedir. Bunu destekler şekilde, akciğerlerde dengesiz bir ekosistem varlığı solunum sistemi hastalıklarının gelişimine yatkılık oluşturabilmektedir. Akciğer mikrobiyomundaki kantitatif ve kalitatif değişiklikler, bir dizi pulmoner hastalıkta progresyon ve alevlenmelerle ilgili olabilmektedir. Bunun yanı sıra son zamanlarda, bağırsak ve akciğer arasındaki immünolojik ilişki tartışılmaktadır. Bağırsak kaynaklı inflamatuar metabolitlerin mezenterik lenf yoluyla dolaşıma girmesi immüno-inflamasyona yol açabilmektedir. Sistemik inflamasyon ve çoklu organ yetmezliğinin gelişiminde mezenterik lenfin önemli bir rol oynadığı düšünülmektedir. Esas olarak portal sistemden ziyade mezenterik lenfte bulunan bağırsak kaynaklı faktörlerin akciğer hasarının gelişimini güçlendirebileceği öne sürülmektedir [19]. Birçok solunum yolu hastalığında hem akciğer ve hem de bağırsak mikrobiyotasında değişiklik görülebilmektedir. Her iki bölgedeki mikrobiyal disbiyozun hastalığın bir nedeni mi yoksa bir sonucu mu olduğu belirsizliğini korumaktadır. Bununla birlikte 
bağırsak mikrobiyotası, hem bağırsakta hem de akciğerlerde immünite üzerinde önemli bir etkiye sahip olduğundan akciğer mikrobiyotasının homoestaz üzerine direkt etkilerini gözlemlemek zorlaşmaktadır [20].

Bağırsak mikrobiyotasının akciğer homeostazı ve immünitesindeki rolü, akut enfeksiyonlara maruz kalan germ-free fareler ile gösterilmiştir. Fagundes ve ark. [21] bu çalışma ile bağırsağın kommensal mikrobiyota tarafından kolonizasyonun, konağın çevresel bulaşıcı uyaranlara tepki verme şeklini etkilediğini göstermektedir. Simbiyotik bağırsak kolonizasyonu, konakçının karşıllaştığı zararlı patojenlere karşı uygun inflamatuar yanıtı desteklemektedir [21]. Güncel araştırmalar, bağırsak mikrobiyotasının belirli üyelerinin akciğerler de dahil olmak üzere sistemik immünite üzerindeki etkilerine ve ayrıca akut ve kronik akciğer hastalığını önlemek ve tedavi etmek için probiyotik ve prebiyotiklerin kullanımına odaklanmaktadır. Bununla birlikte mikrobiyotadaki değişiklikler ile akciğer immünitesini ilişkilendiren uzunlamasına çalışmalara intiyaç duyulmaktadır [22].

\section{COVID-19 ve Bağırsak-Akciğer Ekseni}

Yeni SARS-CoV-2'nin bağırsak mikrobiyotasına etki edebileceği ya da bağırsak mikrobiyotasının hastalığın süreci üzerinde etkisinin olabileceği gibi ilginç fikirler ortaya konulmaktadır [15]. Literatürde, solunum yolu enfeksiyonlarının bağırsak mikrobiyotasında değişikliklerle ilişkili olduğunu gösteren çalışmalar bulunmaktadır. Bartley ve ark. [23] farelerde kalori kısıtlamasının influenza enfeksiyonu esnasında bağırsak mikrobiyotası üzerine etkileri ile ilgili bir çalışma gerçekleştirmiştir. Kalori kısıtlaması bağırsak mikrobiyotasında değişimlere yol açmasına rağmen influenza ilişkili immün yanıtta bir değişim yaratmamıştır. Ayrıca influenza enfeksiyonunun bağırsak mikrobiyotası üzerine direkt etkilerine, özellikle Proteobacteria bolluğunda artışa dikkat çekilmektedir. Bu çalışma, özellikle immün yanıtlarının yetersiz olduğu bilinen gruplar için spesifik virüslere karşı immün tepkileri kolaylaştırmak üzere mikrobiyota modülasyonuna öncülük edebilecek niteliktedir [23].

COVID-19'un ciddi klinik belirtilerinden biri zatürree ve özellikle yaşlı, bağışıklığı zayıflamış hastalarda ARDS şeklindedir [15]. Bağırsak mikrobiyotasının sepsis ve ARDS patogenezinde önemli bir rol oynadığını ileri sürülmektedir. Bağırsak bakteri çeşitliliğinin azalması, disbiyoza yol açabilmektedir ve yaşlı bireylerde bağırsak mikrobiyota çeşitliğinin daha az olduğu bilinmektedir. Yaşla birlikte Bifidobacterium spp. gibi faydalı mikroorganizmaların sayıları azalmaktadır ve bunun sonucunda patojen mikroorganizmalar için ortam oluşmaktadır. Pek çok yaşlı ve immün sistemi zayıflamış hastada ciddi olumsuz klinik sonuçlar görülebildiğinden, COVID-19'da akciğer ve bağırsak mikrobiyotası arasında hastalı̆ı̆ sonucunu etkileyebilecek bir ilişkinin muhtemel olabileceği düşünülmektedir [15]. Bununla ilgili olarak Gou ve ark. [24] COVID-19'da hastalık sürecinin şiddetlenmesini öngören 20 proteomik kan biyobelirteçine dayalı bir risk skoru oluşturmuşlardır. Bunun için enfeksiyonsuz 990 kişiden oluşan bir kohort çalışması gerçekleştirmişlerdir. Çalışma sonuçları, COVID-19 için kan proteomik risk skorunun yaşlı bireyler arasında proinflamatuar sitokinlerle pozitif olarak ilişkili olduğunu göstermektedir. Ayrıca bu çalışma bağırsak mikrobiyota özelliklerinin, 301 kişi için COVID-19 proteomik biyobelirteçlerini doğru bir şekilde tahmin edebileceğini göstermiştir. Çalışmanın sonuçları, sağlıklı bireylerde COVID-19 hastalık şiddetinin bağırsak mikrobiyotası ile ilişkili olduğunu ve açıklayıcı bir mekanizma niteliği taşıdığını düşündürmektedir [24]. Zuo ve ark. [25] COVID-19'lu 15 hastada yapmış olduğu bir pilot çalışmada, kontrollere kıyasla hastaneye yatış yapan hastalarda fekal mikrobiyom değişiklikleri saptanmıştır. Bu değişiklikler fırsatçı patojenlerin artması ve faydalı mikroorganizmaların azalması şeklinde tanımlanmıştır ve bu hastalarda görülen fekal mikrobiyom değişiklikleri COVID-19 şiddeti ile ilişkilendirilmiştir [25].

COVID-19'un immün yanıt ile ilgili olumsuz sonuçlara neden olduğu bilinmektedir. Artmış proinflamatuar sitokinler ve kemokin üretimi, akciğerde ARDS ve çoklu organ yetmezliğine yol açan "sitokin fırtınasına" neden olmaktadır [26]. SARS koronavirüslerinin, akciğer epiteline ek olarak immün sistem hücrelerini de enfekte ettiği gösterilmiştir ve şiddetli immün yanıt, virüsün immün hücre hasarında önemli bir role sahiptir [27]. İnfluenzaya benzer bir şekilde diğer viral enfeksiyonların neden olduğu immün yanıtlar da bağırsak mikrobiyotasında bozulmalar ve disbiyozla sonuçlanabilmektedir ve bu durum ise bakteriyel pnömoniye neden olabilmektedir. Bağırsak mikrobiyotası ile immün sistem arasındaki denge halinde olan çift yönlü etkileşimde bozulma açığa çıktığında inflamatuar süreçler başlamaktadır. Bağırsakta artan inflamasyon, bakteriyel antijenlerin ve toksinlerin sistemik dolaşıma geçmesine izin vermektedir ve bu COVID-19'lu hastaların septik durumunu daha da kötüleştirmektedir [26]. Sepsis ve ARDS görülen hastalarda akciğer mikrobiyotası ve bağırsak mikrobiyotası arasında etkileşim söz konusudur [18]. Bağırsak geçirgenliğine bağıı olarak sepsis ve ARDS'de bağırsaktan akciğerlere bakteriyel translokasyon görülebilmektedir [28]. Bağırsak 
ve solunum sisteminin immün tepkileri düzenlemede bağlantılı olduğu ve bağırsak mikrobiyotasında görülen disbiyozun solunum yolundaki hastalık patogenezine katkıda bulunduğu düşünülmektedir [26]. Bu bakımdan, bağırsak mikrobiyotasını modüle etmeye yönelik stratejilerin, hastalığın şiddetinin azaltılmasında etkili olabileceği öngörülmektedir [7].

\section{Diyetin Bağırsak-Akciğer Ekseni ve COVID-19 Üzerine Potansiyel Etkileri}

Enfeksiyon sürecinde ve öncesinde yeterli ve dengeli beslenme, immün sistemi desteklemek için oldukça önemlidir [29]. Makro besinlerin (karbonhidratlar, yağlar ve proteinler) ve mikro besinlerin (vitaminler ve mineraller) yeterli ve dengeli alımı; nötrofil ve makrofajların fagositik fonksiyonları, lenfosit farklılaşması, antikor ve sitokin üretimi üzerindeki etkileri ile doğal ve adaptif immüniteyi etkilemektedir [30]. Bu nedenle, COVID-19 sürecinde sağlıklı bir diyet sağlanmalı, yaş ve cinsiyete göre tüketilmesi gereken günlük et grubu, süt gurubu, tahıl grubu, sebze ve meyve grupları önerilere uygun olarak tüketilmelidir [29]. COVID-19 pandemisi sırasında sağlıklı bir diyete ilişkin çeşitli beslenme otoritelerinin güncel önerileri bulunmaktadır. Genel öneriler ağırlıklı olarak meyve, sebze, kepekli tahıllar, az yağlı süt ürünleri ve sağlıklı yağlar (zeytinyağı ve balık yağı) gibi taze gıdalara dayalı bir diyetin tercih edilmesi ve şekerli içeceklerin, kalori ve tuz içeriği yüksek işlenmiş gıdaların alımının sınırlandıııması şeklindedir [31]. Sağlıklı bir diyet aynı zamanda bağırsak mikrobiyotasının şekillenmesinde önemli bir rol oynamaktadır ve bağırsak mikrobiyotası immün sistemin düzenlenmesine etkilidir. Farklı diyet örüntülerinin bağırsak mikrobiyota kompozisyonu üzerine farklı etkileri görülebilmektedir. Örneğin, bağırsak mikrobiyota kompozisyonu, hayvansal yağ ve protein bazlı diyetler ile sebze bazlı diyetlere göre farklılık göstermektedir [32]. Yüksek yağ veya yüksek şeker içeriği olan sağlıksız bir diyetle beslenmenin bağırsak mikrobiyotasını olumsuz etkilediği ve sirkadyen ritim bozulmasına neden olduğu bildirilmiştir [33]. Bu bakımdan diyet ile ilgili faktörlerin bağırsak mikrobiyotasında ve fonksiyonunda değişikliğe neden olabileceği ve bu durumun immün sistem üzerine etkisi göz önünde bulundurulmalıdır [32].

Bağırsak-akciğer ekseni boyunca etki gösteren çeşitli diyet faktörlerinden bahsedilmektedir ve bunlardan bir tanesi de immünomodülatör bir metabolit olan kısa zincirli yağ asitleridir. Sindirilemeyen diyet liflerinin bağırsak mikrobiyotası tarafından fermantasyonu, propiyonat, asetat ve bütirat gibi kısa zincirli yağ asitlerinin (KZYA) üretimiyle sonuçlanmaktadır. KZYA'lar epitel hücreleri ve immün hücreleri dahil olmak üzere çeşitli hücrelerin işlevini doğrudan veya dolaylı olarak etkileyebilmektedir. KZYA'lar, bağırsaktan kemik iliğine ulaşmak üzere kan dolaşımına yayılmaktadır ve bunun sonucunda hematopoez indüklenmektedir. İnfluenza enfeksiyonu sırasında bütirat ve propiyonat, monositlerin proliferasyonunu arttırarak kemik iliğinde ve akciğerlerde Ly6C- monositlerinin çoğalmasına yol açmaktadır. Ly6C-monositleri, CXCL1 (C-X-C Motif Kemokin Ligandı 1, nötrofil kemoatraktan)'in ekspresyonunu azaltan makrofajlara farklılaşabilmektedir. Böylelikle nötrofil akışı azalmakta, bu da influenza aracılı akciğer immünopatolojisinde düşüş ile sonuçlanmaktadır. Ayrıca, KZYA'lar, metabolizmalarını ve dolayısıyla antiviral aktivitelerini arttırarak influenzaya özgü CD8 + T (sitotoksik T) hücrelerinin aktivasyonunu doğrudan etkileyebilmektedir [17]. Lokal ve sistemik KZYA seviyeleri, diyetin fermente edilebilir lif içeriğine ve bu lifleri fermente edebilen mikrobiyal topluluğa büyük ölçüde bağlıdır. Benzer şekilde diyet lifleri, Firmicutes/Bacteroidetes oranını değiştirerek bağırsak mikrobiyomunu şekillendirebilir ve KZYA fermantasyon kapasitesini arttıran Bacteroideteslerin çoğalmasını teşvik edebilir [34]. Fermente edilebilir lif bakımından zengin bir diyetle beslenen farelerde, fekal ve serum KZYA artışı ile influenza virüsü enfeksiyonuna bağlı akciğer hasarı azalmıştır ve sağ kalım arttırmıştır [35]. Solunum yolu hastalıklarına karşı koruyucu etkileri göz önüne alındığında, KZYA'lar umut verici bir yaklaşım olabilir. Bununla birlikte KZYA'ların bağırsak-akciğer ekseni boyunca anti-inflamatuar ve immün modülatör etkileri ile ilgili daha fazla çalışmaya gereksinim duyulmaktadır [17].

Prebiyotikler, mikrobiyota tarafından seçici olarak kullanılan ve sağlık yararı gösteren substratlar olarak tanımlanmaktadır. Prebiyotikler, mikrobiyota kompozisyonu üzerindeki etkilerine ek olarak, ayrıca bağışıklık ve metabolik belirteçlerde kayda değer değişiklikler sağlamaktadır. Prebiyotiklerin yararlı etkilerinin çoğunlukla artan KZYA üretiminden geldiği düşünülmektedir [36]. Prebiyotik lif bakımından zengin bir diyetin yalnızca bağırsak mikrobiyotasını etkilemekle kalmayıp aynı zamanda akciğer mikrobiyotasını da etkileyebileceği gösterilmiştir. Bu bakımdan prebiyotik besinlerden zengin bir beslenme modelinin akciğer immünitesi üzerinde önemli bir etkisi söz konusu olabilir [34]. Probiyotikler ise yeterli miktarlarda alındıklarında konakçıya sağlık yararı sağlayan canlı mikroorganizmalar olarak tanımlanmaktadır [37]. Probiyotikler, inflamatuar süreçlerin iyileştirilmesinin yanı sıra, toll-benzeri reseptörleri (Toll-like receptors) ve sinyal yollarını kullanarak immün düzenlenmede olumlu sonuçlar göstermiştir [38]. COVID-19 enfeksiyonuna karşı potansiyel taşıyan 
probiyotikler, yalnızca patojen türler tarafından kolonizasyonu azaltmakla kalmayıp, aynı zamanda solunum yolundaki kommensal bakteri büyümesini de arttırabilir. Kommensal bakteri türleri, aynı aileye veya cinse ait patojenlerin büyümesini baskılayabilir, bu da homeostazı sürdürmede oldukça önemli bir faktördür [16]. Oral probiyotiklerin bağırsak-akciğer eksenini modüle ederek antiviral etkiler gösterebileceği düşünülmektedir. Probiyotiklerin kommensal mikroorganizmalar ve mukozal immünite arasındaki etkileşimi düzenlediği ve bu şekilde viral enfeksiyonlara yanıt olarak bazal ve indüklenmiş inflamatuar dengeyi değiştirdiği anlaşılmıştır. Üst solunum yolu hastalıkları ile ilgili olarak, bazı probiyotikler anti-viral koruyucu etkiler göstermekte olup, enfeksiyon ve inflamasyondan kaynaklanan doku hasarının şiddetini ve kapsamını azaltabilmektedir [39]. Dünya çapında artan klinik çalışmalar, solunum yolunda şiddetli inflamasyona neden olan sitokin fırtınasının COVID-19 hastalığının şiddeti ile pozitif bir korelasyona sahip olduğunu göstermektedir [1]. Bugüne kadar elde edilen veriler, antiinflamatuar veya immüno-modülatör özelliklere sahip probiyotiklerin, COVID-19 semptomlarını önlemek veya hafifletmek için faydalı potansiyele sahip olabileceğine işaret etmektedir (39). Bununla birlikte, probiyotik tedavisi işlevsel ve ümit verici görünmesine rağmen, yeterli kanıtlar olmamakla birlikte bağırsak bakterilerinin fermantasyon etkisine bağı olarak şişkinlik gibi rahatsız edici yan etkilere yol açma dezavantajına sahiptir [16].

Diyetin bir bütün olarak ele alınması bağırsak mikrobiyota düzenlenmesinde önemli bir faktördür. Makro besinler, mikro besinler ve polifenoller dahil olmak üzere besin bileşenleri alımlarının bağırsak mikrobiyotası üzerinde önemli bir etki sergilediği bilinmektedir. Fenoller, flavonoidler ve lignanlar gibi polifenoller çiğ sebze ve meyvelerde bol miktarda bulunmaktadır. Kahve, çay ve şarap gibi içecekler ile çiğ sebze ve meyvelerin bağırsak mikrobiyotasını büyük ölçüde modüle ederek Lactobacillus gibi potansiyel olarak yararlı organizmaların büyümesini destekleyebileceğinden bahsedilmektedir. Bu besinlerde bulunan polifenoller, Bifidobacteria, Akkermansia ve Fecalibacteria gibi faydalı türlerin artışını teşvik ederken, Helicobacter pylori ve Staphylococcus türleri gibi potansiyel olarak patojenik bakterilerin büyümesini inhibe edebilmektedir. Polifenollerin Firmicutes/Bacteroides oranını etkilediği ve bunun polifenollerin prebiyotik benzeri aktivitesi ile ilişkili olduğu düşünülmektedir [40]. Benzer şekilde antioksidan etki gösteren E vitamini takviyesinin Firmicutes/Bacteroides oranını azaltığı ve sağlığa yararılı mikrobiyotayı modüle ettiği bulunmuştur [41]. A vitamininin bağırsak immün hücreleri ve mikrobiyata üzerindeki etkilerinin de bağırsak bariyer bütünlüğünü etkilediği bildirilmektedir. D vitamininin ise antimikrobiyal peptitlerin ( $\beta$-defensin, katelisidin) salgılanmasın ve ZO-1 ve okludin proteinlerinin ekspresyonunu desteklediğine dair kanıtlar bulunmaktadır. $\mathrm{K}$ vitamininin bağırsak inflamasyonu ve immün fonksiyonunun düzenlenmesi yoluyla bağırsak mikrobiyotasının devamlılığında rol oynadığı düşünülmektedir [42]. Bununla birlikte öneride bulunabilmek için bağırsak mikrobiyotasını ve immün sistemi düzenlemeye yönelik vitamin takviyeleri ile ilgili daha fazla veriye intiyaç duyulmaktadır [40]. Bu besin ögelerini takviyelerinden ziyade yeterli ve dengeli beslenme ile doğal yollardan elde etmek büyük önem taşımaktadır. Vitamin ve mineral takviyelerinin mega dozlarda alınması ve gereksiz yere kullanımı sağlık yararlarından ziyade toksisite gibi risklerle ilişkilendirildiği unutulmamalıdır [31].

Diyet aracılığı ile bağırsak-akciğer eksenini düzenlemenin COVID-19 tedavisini destekleyeceği düşünülmektedir. Asemptomatik hastalar, hafif semptomları olan veya karantinadaki hastalar gibi kendi diyetlerini uygulayabilen COVID-19 hastaları için kepekli tahıllar, baklagiller, meyveler ve sebzeler gibi besinlerin tüketilmesi önerilmektedir [16]. Bu tür bir diyetin vurgulanmasının nedeni, diyet lifi tüketimi ile güçlü inflamatuar belirteçlerden C-reaktif protein, IL (interlökin)-6, IL-18 ve tümör nekroz faktör-alfa (TNF- a) serum seviyeleri arasında ters korelasyon saptanmış olmasıdır [43]. Aynı zamanda yüksek lifli diyetler, daha düşük glikoz konsantrasyonları ve anti-inflamatuar özelliklere sahip adiponektinin daha yüksek plazma konsantrasyonları ile ilişkilidir. SARS-CoV-2'nin patogenezinde, IL6, TNF- $\alpha$ ve IL-12 dahil olmak üzere pro-inflamatuar sitokinlerin aşırı miktarda salıııı gözlemlenmektedir. Bu açıdan C-reaktif protein seviyelerini azaltmada, semptomları hafifletmede ve oksijen alımını iyileştirmede etkinlik gösteren tocilizumab dahil olmak üzere, koronavirüse karşı immünosüpresif ilaçlar test edilmektedir. Dolayısıyla diyet lifinin anti-inflamatuar etkilerinin, antiviral ve immünosupresif ilaç tedavilerinin etkisini güçlü bir şekilde destekleyebileceği söylenebilir [16].

COVID-19 ve bağırsak-akciğer ekseni ilişkisi göz önüne alındığında özellikle kişiselleştirilmiş, bütüncül bir diyet, COVID-19'dan etkilenen hastalarda iyileşmeyi hızlandırmak ve klinik sonuçları geliştirmek için umut vadeden bir yaklaşım olabilir [15]. Bununla birlikte hiçbir diyet veya besin takviyesinin COVID-19 enfeksiyonunu önleyemeyeceği unutulmamalıdır [29]. Spesifik besin ögelerinin bağırsakakciğer ekseni ve COVID-19 enfeksiyonu üzerine etkilerine yönelik daha fazla klinik çalışmaya ihtiyaç duyulmaktadır [15]. 


\section{Tartışma ve Sonuç}

Dünyanın büyük bir mücadele içinde olduğu yeni SARS-CoV2 enfeksiyonunun mekanizmalarını anlamak, önlenmesi ve tedavisi için potansiyel yeni hedefler yaratabilir. COVID-19 ile ilişkili kötü klinik sonuçların ve ölümlerin büyük çoğunluğu, yaşıılık ve bir veya daha fazla komorbiditenin varlığı gibi spesifik risk faktörleri olan ve aynı zamanda sağıksız mikrobiyom ile de karakterize edilen bireylerde gelişmektedir [44]. Bu nedenle, bağırsak disbiyozunun COVID-19 klinik görünümü de etkileme olasılığının oldukça yüksek olduğu düşünülmektedir. Bağırsak mikrobiyotası çevresel koşullardan etkilendiği ve özellikle diyet ile modüle edilebildiği için COVID-19 tedavisinde ek bir strateji olarak öne sürülmektedir [32]. Diyet lifi ve prebiyotikler KZYA üretimini arttırmaktadır ve KZYA seviyeleri immünoregülasyon için önemli bir faktördür. Bu tür diyet yaklaşımları, özellikle yaşılıarda ve SARSCoV-2 virüsü ile enfekte olan bağışıklık sistemi zayıflamış hastalarda iyileşmeyi hızlandırmak için umut vadedebilir [15].

Bağırsak-akciğer eksenini hedef almanın COVID-19 enfeksiyonunda tedaviye ek bir rol oynayacağına dair klinik verilerin kısıtlı olmasına rağmen, probiyotikler, prebiyotikler ve yüksek lifli bir diyet aracılığı ile inflamasyonu azaltma, sağlıkı bir bağırsak mikrobiyota çeşitliliğini koruma ve immün sistemi güçlendirme gibi faydalar sağlanabilir [16]. Diyetin bir bütün olarak ele alınması, kişiselleştirilmiş olması bağırsak mikrobiyota düzenlenmesinde önemli bir faktördür [40]. Makro ve mikro besinler, polifenoller gibi besin ögelerinin bağırsak mikrobiyotası üzerinde immün sistemi destekleyici ve immün yanıtı düzenleyici önemli etkileri bulunabilir. Bu nedenle, etkili bir beslenme stratejisi ve spesifik gruplar için mikrobiyotayı hedef alan fonksiyonel gıdalar, tedavi için daha detaylı incelenmelidir. COVID-19'un bağırsak mikrobiyotası üzerindeki etkileri ve bağırsak mikrobiyotasının diyet ile ilişkisinin COVID-19 süreci üzerine etkileri ile ilgili daha fazla çalışmaya intiyaç duyulmaktadır.

\section{Kaynakça}

[1] Zabetakis I, Lordan R, Norton C, Tsoupras A. COVID-19: The Inflammation Link and the Role of Nutrition in Potential Mitigation. Nutrients. 2020;12(5).

[2] Viana SD, Nunes S, Reis F. ACE2 imbalance as a key player for the poor outcomes in COVID-19 patients with age-related comorbidities - Role of gut microbiota dysbiosis. Ageing Res Rev. 2020;62:101123.

[3] Buonaguro L, Tagliamonte M, Tornesello ML, Buonaguro FM. SARS-CoV-2 RNA polymerase as target for antiviral therapy. J Transl Med. 2020;18(1):185.

[4] Jiang F, Deng L, Zhang L, Cai Y, Cheung CW, Xia Z. Review of the Clinical Characteristics of Coronavirus Disease 2019 (COVID-19). J Gen Intern Med. 2020;35(5):1545-9.

[5] Li G, Fan Y, Lai Y, Han T, Li Z, Zhou P, et al. Coronavirus infections and immune responses. J Med Virol. 2020;92(4):424-32.

[6] Xu Z, Shi L, Wang Y, Zhang J, Huang L, Zhang C, et al. Pathological findings of COVID-19 associated with acute respiratory distress syndrome. Lancet Respir Med. 2020;8(4):420-2.

[7] Zhou F, Yu T, Du R, Fan G, Liu Y, Liu Z, et al. Clinical course and risk factors for mortality of adult inpatients with COVID-19 in Wuhan, China: a retrospective cohort study. Lancet. 2020;395(10229):1054-62.

[8] Mehta P, McAuley DF, Brown M, Sanchez E, Tattersall RS, Manson JJ, et al. COVID-19: consider cytokine storm syndromes and immunosuppression. Lancet. 2020;395(10229):1033-4.

[9] Chan KH, Poon LL, Cheng VC, Guan Y, Hung IF, Kong J, et al. Detection of SARS coronavirus in patients with suspected SARS. Emerg Infect Dis. 2004;10(2):294-9.

[10] Wu Y, Guo C, Tang L, Hong Z, Zhou J, Dong X, et al. Prolonged presence of SARS-CoV-2 viral RNA in faecal samples. Lancet Gastroenterol Hepatol. 2020;5(5):434-5.

[11] Chan JF, Yuan S, Kok KH, To KK, Chu H, Yang J, et al. A familial cluster of pneumonia associated with the 2019 novel coronavirus indicating person-to-person transmission: a study of a family cluster. Lancet. 2020;395(10223):514-23.

[12] Ferolla SM, Armiliato GN, Couto CA, Ferrari TC. The role of intestinal bacteria overgrowth in obesityrelated nonalcoholic fatty liver disease. Nutrients. 2014;6(12):5583-99. 
[13] Augustyn M, Grys I, Kukla M. Small intestinal bacterial overgrowth and nonalcoholic fatty liver disease. Clin Exp Hepatol. 2019;5(1):1-10.

[14] Zalar B, Haslberger A, Peterlin B. The Role of Microbiota in Depression - a brief review. Psychiatr Danub. 2018;30(2):136-41.

[15] Dhar D, Mohanty A. Gut microbiota and Covid-19- possible link and implications. Virus Res. 2020;285:198018.

[16] Conte L, Toraldo DM. Targeting the gut-lung microbiota axis by means of a high-fibre diet and probiotics may have anti-inflammatory effects in COVID-19 infection. Ther Adv Respir Dis. 2020;14:1753466620937170.

[17] Dang AT, Marsland BJ. Microbes, metabolites, and the gut-lung axis. Mucosal Immunol. 2019;12(4):84350.

[18] Acarkan T, Erdoğan D, Kacar M. Covid-19 ile mücadelede akciğer ve bağırsak mikrobiyotalarının rolü. Anatolian Clinic the Journal of Medical Sciences. 2020;25(Special Issue on COVID 19):284-93.

[19] He Y, Wen Q, Yao F, Xu D, Huang Y, Wang J. Gut-lung axis: The microbial contributions and clinical implications. Crit Rev Microbiol. 2017;43(1):81-95.

[20] Dumas A, Bernard L, Poquet Y, Lugo-Villarino G, Neyrolles O. The role of the lung microbiota and the gut-lung axis in respiratory infectious diseases. Cell Microbiol. 2018;20(12):e12966.

[21] Fagundes CT, Amaral FA, Vieira AT, Soares AC, Pinho V, Nicoli JR, et al. Transient TLR activation restores inflammatory response and ability to control pulmonary bacterial infection in germfree mice. $\mathrm{J}$ Immunol. 2012;188(3):1411-20.

[22] Budden KF, Gellatly SL, Wood DL, Cooper MA, Morrison M, Hugenholtz P, et al. Emerging pathogenic links between microbiota and the gut-lung axis. Nat Rev Microbiol. 2017;15(1):55-63.

[23] Bartley JM, Zhou X, Kuchel GA, Weinstock GM, Haynes L. Impact of Age, Caloric Restriction, and Influenza Infection on Mouse Gut Microbiome: An Exploratory Study of the Role of Age-Related Microbiome Changes on Influenza Responses. Front Immunol. 2017;8:1164.

[24] Gou W, Fu Y, Yue L, Chen G-d, Cai X, Shuai M, et al. Gut microbiota may underlie the predisposition of healthy individuals to COVID-19. medRxiv. 2020:2020.04.22.20076091.

[25] Zuo T, Zhang F, Lui GCY, Yeoh YK, Li AYL, Zhan H, et al. Alterations in Gut Microbiota of Patients With COVID-19 During Time of Hospitalization. Gastroenterology. 2020;159(3):944-55.e8.

[26] Aktas B, Aslim B. Gut-lung axis and dysbiosis in COVID-19. Turk J Biol. 2020;44(3):265-72.

[27] Gu J, Gong E, Zhang B, Zheng J, Gao Z, Zhong Y, et al. Multiple organ infection and the pathogenesis of SARS. J Exp Med. 2005;202(3):415-24.

[28] Dickson RP, Singer BH, Newstead MW, Falkowski NR, Erb-Downward JR, Standiford TJ, et al. Enrichment of the lung microbiome with gut bacteria in sepsis and the acute respiratory distress syndrome. Nat Microbiol. 2016;1(10):16113.

[29] Muslu M, Ersü DÖ. Yeni Koronavirüs (SARS-CoV-2/COVID-19) Pandemisi Sırasında Beslenme Tedavisi ve Önemi. Beslenme ve Diyet Dergisi. 2020;48(1):73-82.

[30] Tamer A, Nalbant A. Beslenme ve Bağışıklık Sistemi. Sakarya Tıp Dergisi.11(2):458-66.

[31] de Faria Coelho-Ravagnani C, Corgosinho FC, Sanches FLFZ, Prado CMM, Laviano A, Mota JF. Dietary recommendations during the COVID-19 pandemic. Nutr Rev. 2021;79(4):382-93.

[32] Wu GD, Chen J, Hoffmann C, Bittinger K, Chen YY, Keilbaugh SA, et al. Linking long-term dietary patterns with gut microbial enterotypes. Science. 2011;334(6052):105-8.

[33] Voigt RM, Forsyth CB, Green SJ, Mutlu E, Engen P, Vitaterna MH, et al. Circadian disorganization alters intestinal microbiota. PLoS One. 2014;9(5):e97500.

[34] Trompette A, Gollwitzer ES, Yadava K, Sichelstiel AK, Sprenger N, Ngom-Bru C, et al. Gut microbiota metabolism of dietary fiber influences allergic airway disease and hematopoiesis. Nat Med. 2014;20(2):159-66. 
[35] Trompette A, Gollwitzer ES, Pattaroni C, Lopez-Mejia IC, Riva E, Pernot J, et al. Dietary Fiber Confers Protection against Flu by Shaping Ly6c(-) Patrolling Monocyte Hematopoiesis and CD8(+) T Cell Metabolism. Immunity. 2018;48(5):992-1005.e8.

[36] Gibson GR, Hutkins R, Sanders ME, Prescott SL, Reimer RA, Salminen SJ, et al. Expert consensus document: The International Scientific Association for Probiotics and Prebiotics (ISAPP) consensus statement on the definition and scope of prebiotics. Nat Rev Gastroenterol Hepatol. 2017;14(8):491-502.

[37] Hill C, Guarner F, Reid G, Gibson GR, Merenstein DJ, Pot B, et al. Expert consensus document. The International Scientific Association for Probiotics and Prebiotics consensus statement on the scope and appropriate use of the term probiotic. Nat Rev Gastroenterol Hepatol. 2014;11(8):506-14.

[38] West CE, Dzidic M, Prescott SL, Jenmalm MC. Bugging allergy; role of pre-, pro- and synbiotics in allergy prevention. Allergol Int. 2017;66(4):529-38.

[39] Baindara P, Chakraborty R, Holliday ZM, Mandal SM, Schrum AG. Oral probiotics in COVID-19: connecting the gut-lung axis to viral pathogenesis, inflammation, secondary infection, and clinical trials. New Microbes New Infect. 2021:100837.

[40] Rishi P, Thakur K, Vij S, Rishi L, Singh A, Kaur IP, et al. Diet, Gut Microbiota and COVID-19. Indian J Microbiol. 2020;60(4):1-10.

[41] Choi Y, Lee S, Kim S, Lee J, Ha J, Oh H, et al. Vitamin E ( -tocopherol) consumption influences gut microbiota composition. Int J Food Sci Nutr. 2020;71(2):221-5.

[42] Stacchiotti V, Rezzi S, Eggersdorfer M, Galli F. Metabolic and functional interplay between gut microbiota and fat-soluble vitamins. Crit Rev Food Sci Nutr. 2020:1-22.

[43] Buyken AE, Goletzke J, Joslowski G, Felbick A, Cheng G, Herder C, et al. Association between carbohydrate quality and inflammatory markers: systematic review of observational and interventional studies. Am J Clin Nutr. 2014;99(4):813-33.

[44] Donati Zeppa S, Agostini D, Piccoli G, Stocchi V, Sestili P. Gut Microbiota Status in COVID-19: An Unrecognized Player? Front Cell Infect Microbiol. 2020;10:576551. 